THE ATTLEE GOVERNMENT, THE IMPERIAL PREFERENCE SYSTEM, AND THE CREATION OF THE GATT

RICHARD TOYE 


\section{THE ATTLEE GOVERNMENT, THE IMPERIAL PREFERENCE SYSTEM, AND THE CREATION OF THE GATT ${ }^{1}$}

During September 1947, Anglo-American economic diplomacy met with a crisis, hard on the heels of that which had attended the suspension of sterling convertibility the previous month. The multilateral trade talks taking place in Geneva, which were aimed both at the eventual creation of an International Trade Organization (ITO), and at securing substantial reductions in barriers to world trade, had run into major problems. Accordingly, Ernest Bevin, the British Foreign Secretary, and Sir Stafford Cripps, the President of the Board of Trade, met with William L. Clayton, US Under-Secretary of State for Economic Affairs, and Lewis W. Douglas, the US ambassador to London. Clayton emphasised strongly that, unless the British made substantial steps towards the elimination of her imperial preference trading system, 'the Americans would look upon it as a repudiation of one of the important conditions' of the 1945 US loan to Britain. Douglas stepped in to say that, unless she amended her attitude, Great Britain might well get left out of any help given to Europe under the recently-announced Marshall Plan. ${ }^{2}$ In the British view, this was 
'blackmail'. ${ }^{3}$ In reality, it was 'conditionality', for the Americans were not demanding money with menaces, but were attaching strings to their own offer of financial help. Yet, even though the UK did not agree to dismantle the imperial preference system, the Americans failed to carry out their threats. The following month, Britain, the USA, and thirteen other countries signed the General Agreement on Tariffs and Trade (GATT). This supposedly interim agreement, which was meant to provide a framework for tariff reductions in advance of the creation of the ITO, in fact continued as the basis on which world trade was regulated, until it was superseded by the World Trade Organization (WTO) in 1995.

Attlee's ministers, therefore, had done three things which, at first sight, might seem rather surprising. First, although Britain was in a state of profound economic weakness, and dependent on future American assistance, they had refused to cave in to a direct threat that such assistance would be withheld. Second, in so doing, although they had a powerful (if not unchallengeable) claim to be genuinely anti-imperialist, they had successfully defended the imperial preference system. ${ }^{4}$ Third, although they professed themselves to be socialists, to whom free trade might have been expected to be anathema, they had signed an international agreement the aim of which, broadly speaking, was to move towards freer trade. What was 
the significance of these (in some ways rather contradictory) achievements, and by what processes did they come about?

In order to answer these questions, it is necessary to examine in detail the 1947 Geneva negotiations and the attendant decisions taken by ministers. British historians of the Attlee government, have not, to date, done this. This is, perhaps, a less surprising omission in general accounts of the period than it is in specialised accounts of the Labour government's economic policy, and, indeed, in accounts of its external economic policy in particular. ${ }^{5}$ American writers, by contrast, have shown rather more interest in the origins of the GATT. Richard N. Gardner's Sterling-Dollar Diplomacy, first published in 1956, still provides, in spite of its occasionally polemical tone, a seminal aid to understanding the issues at stake. However, Gardner's comparatively short account of the Geneva talks themselves was mainly reliant, in its assessment British politicians' intentions, on public pronouncements made by them at the time. ${ }^{6}$ Thomas W. Zeiler's more recent Free Trade Free World (1999) is based on an extremely impressive amount of archival research. But not only is his account of the American motivation for signing the GATT in some ways unsatisfactory, ${ }^{7}$ he also fails to provide a sure guide to British policy. ${ }^{8}$ 
There is room, therefore, for an account of the Attlee's government's role in the Geneva talks that is fuller and more systematic than those previously attempted. That role must be understood in the light of the difficulties Britain experienced in negotiating for the reduction of trade barriers in the face of countervailing pressures. On the one hand, the increasing weakness of Britain's external economic position during 1947 meant that it was dangerous, at least in the short term, to liberalise trade substantially, as this would encourage an influx of imports which would have to be paid for with dollars, which were in very short supply. On the other hand, to refuse to do so would jeopardise the prospect not only of direct American aid, but also that of the US trade concessions which were vitally necessary for the future health of Britain's export trade. In addition, the Attlee government's genuine, if progressively eroding, belief that an ITOtype multilateral world trading regime would help avert a recurrence of the economic errors of the interwar years was matched by a simultaneous desire to undertake socialist planning at the domestic level. Yet as some contemporaries recognised, multilateralism abroad was inconsistent with a high level of planning at home, because freer trade implied letting market forces determine, to a degree at least, the size of particular industries. ${ }^{9}$ 
In spite of these practical and ideological problems, the outcome of the negotiations represented a success for Britain, which, to a striking degree, withstood pressure to fall in with American views on trade. In explaining this outcome - which was surprising given the immense power wielded by the United States at this time - this article will adopt the following structure. First, the wartime and postwar background to the Geneva talks will be outlined. Then, the course of the negotiations themselves will be described, in relation to other major developments such as the launch of the Marshall Plan and the advent and demise of sterling convertibility. Finally, an assessment will be made, not only of why Britain was finally able to reach agreement with the United States, but of why the process took so long, and came so close to breakdown. It will be suggested that the episode yields important lessons about the methods by which Britain, in her weakened postwar condition, resisted, to a significant degree successfully, US attempts at hegemonic imposition. There are also lessons to be drawn about the limits to American power in this period. ${ }^{10}$ The results of the Geneva talks illustrate how even the most powerful nations may be confounded in key aims by countries they might be expected to be able to dominate, if their own objectives are conflicting and if the policy tools they use in the search for hegemony are flawed. 
The wartime discussions that preceded the birth of the GATT led to seminal shift in US trade policy, from a bilateral approach, to a multilateral one. ${ }^{11}$ US planning for the post-war world had started within the State Department as early as 1939, and was predicated at first on the assumption that future progress towards freer trade would be based on a straightforward extension of the reciprocal trade agreements programme initiated in 1934 by Secretary of State Cordell Hull. Joint Anglo-American planning came later, stimulated first by the signature of the Atlantic Charter in August 1941, and given a further boost by the collapse of US isolationist sentiment after Pearl Harbor. Then, on 23 February 1942, Britain committed herself to Article VII of the Mutual Aid Agreement, whereby as 'consideration' for American Lend-Lease aid, there would be 'provision for agreed action by the United States and the United Kingdom ... directed ... to the elimination of all forms of discriminatory treatment in international commerce, and the reduction of tariffs and other trade barriers. $^{12}$ There followed a drawn-out process of Anglo-American negotiation as to the form this consideration should take.

One key official British initiative was John Maynard Keynes's plan for an international clearing union, published in April 1943 at the same time as Harry Dexter White's parallel US plan for an international stabilization fund and reconstruction bank. Another was the 
complementary plan designed by James Meade (a Laboursympathising Keynesian economist and war-time official) for an international commercial union, designed to create a multilateral trading system, from which, Meade believed, Britain was likely to benefit. However - and here were the anticipated indispensable British conditions for participation - both state trading and the continuation of a moderate degree of Imperial Preference' would be permitted. ${ }^{13}$ These proposals formed the framework of the Anglo-US Article VII discussions which took in Washington during the autumn of 1943. As James N. Miller has noted, by the time these discussions began, the British and Americans had, for differing reasons, reached the same conclusion: the world needed a system of multilateralism in trade that involved multilateral clearing, a multilateral negotiating mechanism for the reduction of tariffs, and multilateral inclusion in the design and operation of the system's rules and exceptions. ${ }^{14}$ This, they believed, would be facilitated by the creation of an international trade organisation.

Labour ministers in Churchill's coalition government were, with the notable exception of Ernest Bevin, amongst the strongest British supporters of this agenda. This was in spite of the fact that the Labour Party's programme had, since the early 1930s, been based upon the creation of a planned economy in Britain. ${ }^{15}$ The potential conflict 
between the party's aspirations did not go completely unrecognised. For example, the 1943 Washington proposals - emerging out of the Article VII talks - were warmly welcomed by Sir Stafford Cripps. Cripps was at this time an independent MP and the Minister for Aircraft Production; later, as Attlee's first President of the Board of Trade (1945-7), he would play a crucial role in the GATT talks. In spite of the broad support he leant to the proposals, he also emphasised that 'I should find it very difficult to agree to bartering away our freedom in internal policy unless it were for a politically realistic and practical method of regulating international trade and finance. ${ }^{16}$

This question - to what degree should Britain accept restrictions on her own freedoms as the price of achieving a more satisfactory international economic environment - provided a dilemma for the Attlee government during the postwar trade negotiations. (It was, of course, a dilemma that was by no means unique to Britain.) The problem was exacerbated by the fact that, in spite of their common commitment to the restoration of multilateral trade via an institutionally multilateral forum, the Americans and the British had substantially different ideas of what a 'realistic and practical' method of regulating international trade would be. A key difference in attitude was summed up by James Meade in July 1945: 'there is a very dangerous trend of thought in the USA, of which Will Clayton in the 
State Department may be taken as the symbol, that the way to cure unemployment is to have stable exchange rates and free trade rather than (what is much nearer the truth) that the only way to achieve the conditions in which one can establish freer trade and more stable exchange rates is for countries to adopt suitable domestic policies for maintaining employment.. ${ }^{17}$

The war also had the effect of accentuating US anti-imperialism, and hence American opposition to the imperial preference system, whilst at the same time strengthening British attachment to the system as a means of reinforcing commonwealth ties. ${ }^{18}$ The Labour Party increasingly supported the preference system out of gratitude for the help afforded Britain by the Dominions during the war. ${ }^{19}$ This was almost regardless of the views of the Dominions themselves on the subject: Canada proved an enthusiastic and committed supporter of the American multilateral trade project, $^{20}$ and although the other commonwealth countries were more circumspect, the USA in the end came to view them as more tractable on the preference issue than Britain herself. A further potential problem was that although the 1945 renewal of the 1934 Reciprocal Trade Agreements Act renewal marked a legislative high-point in the US trade liberalization program - the president's authority was extended to allow him to reduce tariffs by up to $50 \%$ of the rates standing on 1 January 1945 - Americans 
tariffs would remain high in comparison to British ones, even if this authority were to be employed to the maximum possible extent. ${ }^{21}$ This limited the extent of the concessions the British would be prepared to make in return during post-war negotiations; and, indeed, their determination only to yield tariff and preference reductions in exchange for adequate compensation eventually paid off.

When the war ended, the issue of trade took on a new importance for the British. The US cut-off of lend-lease in the aftermath of VJ day put it close to the top of the newly-elected Labour government's agenda. Britain was on the verge of bankruptcy, and required substantial American financial aid. The Americans were determined to couple discussion of such help with the elimination of restrictions on postwar trade. ${ }^{22}$ The first formal, post-war negotiations to establish an international commercial policy regime commenced in Washington on 1 October 1945. (The financial talks, which in due course resulted in a \$3.75 billion American loan to Britain, had started on 11 September). During these talks, the British succeeded in getting US agreement for their point of view on the questions of cartels and state trading. But the question of preferences proved much more difficult. The American negotiators found the imperial preference system, which was inherently discriminatory, highly objectionable. ${ }^{23}$ As Lionel Robbins, one of the British team, noted in his diary, it would take a great deal 
to shift the top US officials 'from their conviction that an outright surrender of Imperial Preference is the price necessary to get the financial arrangements through Congress. As this is the one way in which we could not undertake to get rid of prefernces, there is obvious trouble ahead' (emphasis in original). ${ }^{24}$ The British were insistent that, given Britain's economic weakness and the state of her domestic opinion, they could neither afford to eliminate preferences outright, nor could they be seen to do so in exchange for American financial aid, but could only trade them away in exchange for major reductions in US tariffs. ${ }^{25}$ Somewhat paradoxically, then, the weaker party to the negotiations was able to use the very fact of her own economic infirmity as a means of justifying her failure to fit in with important aspects of the stronger party's designs.

This was - and would continue to be - a successful tactic. The Proposals for Consideration by an International Conference on Trade and Employment which emerged from the talks (and which were issued in December 1945 at the same time as the Anglo-US loan agreement) appeared to reflect a victory for the British point of view:

In the light of the principles set forth in Article VII of the mutual aid agreements, members [of the proposed ITO] should enter into arrangements for the substantial reduction of tariffs and for the elimination of tariff preferences, action for the elimination of preferences being taken in conjunction with adequate measures for the substantial reduction of barriers to world trade, as part of the mutually advantageous arrangements contemplated in this document. ${ }^{26}$ 
This was far cry from the language of the original American proposal. ${ }^{27}$ The changed draft made clear, as Secretary of State James Byrnes noted, that 'we are not asking the British to give us a unilateral commitment on preferences in consideration for financial aid and apart from what may be done on tariffs and trade barriers generally' ${ }^{28}$ Nevertheless, the 'mutually advantageous' formula was to some degree ambiguous. Cripps therefore suggested that both sides should agree an explanation, supporting the British interpretation, to be made by the UK government in parliament. ${ }^{29}$ In due course, such a statement was made in the House of Commons by Prime Minister Clement Attlee on 6 December:

We for our part are ready to agree that the existing system of preferences within the British Commonwealth and the Empire will be contracted provided there is adequate compensation in the form of improvement in trading conditions between Commonwealth and Empire countries and the rest of the world ... reduction or elimination of preferences can only be considered in relation to and in return for reductions of tariffs and other barriers to world trade in general.

...all margins of preference will be regarded as open to negotiation, and it will of course be for the party negotiating the modification of any margin of preference which it is bound by an existing commitment to give to a third party, to obtain the consent of the third party concerned. ${ }^{30}$

But when the proposed wording of this statement was presented to the Americans, they took 'violent exception' to this idea that modification of the imperial preference system would be dependent 
on the consent of the Commonwealth countries concerned..$^{31}$ The British argued that, due the contractual nature of the original Ottawa agreements, which had established the system in 1932, in order for a given preference to be abolished by the country that granted it, the country that benefitted from it would have to agree. Therefore, the UK could not pledge unilaterally to abolish preferences, but could only promise to negotiate in good faith for their abolition. ${ }^{32}$

It appears, however, that the British did not stand firm on this point. Although Attlee did go ahead and make his statement, the US representatives also drew up a statement which the British agreed the Americans could make if the necessity arose. As Clayton later recalled, 'That statement provided that if the Dominions were to adopt an unreasonable position regarding the elimination of preferences, the United Kingdom would denounce their agreements with the Dominions. ${ }^{33}$ Of course, what consituted 'unreasonable' behaviour was something that was potentially open to widely differing interpretation - and, arguably, it was unreasonable of the two powers to make a secret arrangement of this nature. In fact, the Americans never did come to perceive Dominion behaviour as sufficiently unreasonable as to merit the proposed action by the British. But, in spite of the original British attempts to ensure clarity, this UK-US pact muddied the waters. Partly as a consequence of this, there remained a 
serious disparity between the two sides' views on how far the UK was obliged to go in the direction of the elimination of preferences. This would become evident during the 1947 Geneva talks. (It also became clear that there were some differences between the Americans themselves on this point.) The British believed that they were fulfilling their obligations merely by negotiating - and that they were not committed in advance to a wholesale elimination of preferences whereas the Americans believed that substantial preference eliminations were required in order to meet the terms of the 1945 agreement. The ambiguity of that agreement therefore helped sustain the Attlee government in its stand against the US position. US attempts to impose 'conditionality', then, were hampered by the imprecision of the original conditions.

It must, however, be stressed that, in spite of these Anglo-American differences, the British government, in the months prior to the opening of the Geneva conference in April 1947, did remain committed to the broad principles underlying the proposed ITO. It was by no means the case that they had accepted trade multilateralism simply as the price of getting the loan. Cripps had stressed in September 1945 that 'provided that our position is safeguarded in certain important respects, a multilateral commercial convention, if one can be obtained, may be very much in our interest. The vital 
objective of a 50 per cent expansion of our exports is not likely to be reached in a world in which the markets of other countries are hedged about by arbitrary and unregulated barriers to trade' (emphasis in original). ${ }^{34}$ Believing that the Anglo-US commercial policy proposals included the necessary safeguards, he became the 'main advocate of the ITO policy' in the British government. (This did not prevent him simultaneously advocating measures of government bulk purchase, of a kind that were anathema to the Americans.) ${ }^{35} \mathrm{He}$ emphasised privately just before the Geneva talks opened that the Government are whole-heartedly behind this attempt to rectify the economic troubles of the world' ${ }^{36}$

Cripps's convictions, however, were by no means fully shared by British opinion more generally. Gardner has argued that in the run-up to the conference there was a hardening of views in favour of retaining imperial preference. He attributes this to three factors: 1) the election in 1946 of a Republican Congress, which was likely to oppose the reduction of US tariffs, 2) President Truman's acceptance of the Republican proposal that future trade agreements should include an 'escape clause', and 3) the conclusion of the 1946 USPhilippine trade agreement, which instituted a preferential tariff arrangement, albeit one which was designed to be progressively eliminated over a long period. ${ }^{37}$ Thus, although the Attlee government, 
and Cripps in particular, continued to hope that the forthcoming conference would be a success - in spite of the fact that they did not anticipate the complete elimination of the preference system - they began to plan for other eventualities. In January 1947, the cabinet agreed to the establishment of a group of outside economists, which would study the alternative polices which might be adopted in the event of a complete or partial breakdown of plans for an ITO. ${ }^{38}$ This was to be kept top secret. As it turned out, the group, which met from March to October, was unable to devise any satisfactory alternative to participation in a multilateral world trading system, and had little impact on policy. ${ }^{39}$

The Geneva talks themselves had been preceeded by a preparatory conference in London in October 1946, which had drawn up a draft charter for the proposed ITO. The Geneva talks, formally speaking, were the second session of this preparatory committee, in advance of a United Nations Conference on Trade and Employment (which was to take place in Havana between November 1947 and March 1948). They were not only aimed at further refining the draft charter, but also involved the first multilateral bargaining process, whereby the fifteen countries present swapped concessions on tariffs and preferences. The concessions made in agreements between pairs of countries would then be generalised to the other countries involved in the talks 
on a most-favoured-nation basis, thus giving the negotiations their 'mutually advantageous' character. These concessions would be incorporated into a general agreement (the GATT), which also included an interim set of commercial policy principles which, it was intended, would in due course be superseded by the ITO charter.

The success of the talks would be dependent on the agreement between America and Britain, the world's two most powerful trading nations, and to a significant degree, on the personal relationship between their respective negotiators-in-chief, Will Clayton and Stafford Cripps. Clayton was the spiritual heir to Cordell Hull in the State Department, and believed in freer trade to a degree that Cripps and other British representatives came to see as fanatical and unrealistic. ${ }^{40}$ There were also other key negotiators to whom there will be further cause to refer. On the British side, Harold Wilson was, after Cripps (to whom he was subordinate), the minister most heavily involved. He was Secretary for Overseas Trade, and was promoted to the position of President of the Board of Trade towards the very end of the talks. At the official level, James Helmore was the most significant figure. He was Second Secretary at the Board of Trade, and, unlike Cripps and Wilson, was almost continually present in Geneva throughout the negotiations. For the American State Department, Clair Wilcox, director of the Office of International Trade 
Policy, and Winthrop G. Brown, chief of the commercial policy division were, after Clayton, the most important individuals. The varying personal talents and dispositions of the negotiators might have mattered little had it been true that, as is sometimes stated, the United States was in a powerful enough position simply to impose the trade policy of its own choosing. ${ }^{41}$ But this proved not to be the case.

Cripps's speech to the opening session of the conference decried the 1930s tendency towards autarchy and self-sufficiency: 'our national prosperity depends upon a world policy of trade expansion to be based upon an extensive international division of labour'. ${ }^{42}$ Yet, at a subsequent press conference, although he emphasised Britain's commitment to the ITO, when 'Asked if an offer by United States of America of the maximum $50 \%$ reduction in her tariff on all requests would be regarded as adequate compensation for the "dismantling" of Imperial Preference, the President replied "No". ${ }^{43}$

(This was because, even if reduced by $50 \%$, US tariffs would remain high by British standards.) Cripps's comment - widely picked up on in the American press - implied that one of the Americans' key aims would be unattainable.

The US government, did not, however, make a great issue of this remark. ${ }^{44}$ The comparatively emollient US stance can be explained 
partly by the appreciation that not all imperial preferences were of major economic significance, and therefore to insist on complete elimination of the system might be unnecessary. All the same, the talks ran into difficulties early on. The Americans had decided to make their full offers of tariff reductions right away and thus make a generous impression. ${ }^{45}$ But this tactic did not have the desired effect of bringing forth generous tariff offers from the other countries. In particular, the results of the negotiations with the British Commonwealth were disappointing. ${ }^{46}$ The alleged paucity of the British offers in particular would be the recurring American theme throughout the Geneva talks. ${ }^{47}$

Crucially, moreover, Clayton thought not only that the British were being profoundly ungenerous, but that, in failing to make what he regarded as decent offers, they were in breach of the 1945 loan agreement. Others in the US delegation were not so sure, pointing out that the British had pledged not to abolish preferences, but merely to negotiate in good faith for their abolition. And the British ability to do this successfully was potentially compromised by the refusal of Australia, at the beginning of the Geneva talks, to waive its contractual rights under the Ottawa agreements. ${ }^{48}$ Clayton thought that the British were merely using this as an excuse, and that, if necessary, the British should unilaterally abrogate their commitments 
to Commonwealth nations in order to live up to her commitments to America under the loan agreement. ${ }^{49}$ But if Clayton's analysis was right, it would mean that the UK would be bargaining away Australian preferences in the UK market, at no loss to the UK, in exchange for a reduction in US duties on British products entering America. Quite reasonably, some US officials insisted that this would be unfair. ${ }^{50}$

Nevertheless, there was some truth in Clayton's allegation that the British were not playing ball. They were not making all possible efforts to secure waivers from Commonwealth countries; rather the reverse. In July, Cripps warned the cabinet that Canada's desire to be released from her own obligations to Britain represented a dangerous breaking of ranks: 'it sets a precedent to break away from agreements on preferences between Commonwealth countries, which ... might lead to a gradual disintegration of the system. ${ }^{51}$ These were not the words of a man negotiating in good faith for the abolition of preferences and frustrated only by the recalcitrance of other countries.

However, the Americans were themselves open to accusations of double-standards. A bill relating to the wool tariff had recently been introduced in Congress, and if this bill became law, it would almost certainly lead to an increase in the wool tariff. ${ }^{52}$ This in turn explained 
Australia's reluctance to liberate Britain to satisfy the Americans by absolving her from her commitments on preferences. Congress's action was not of course the fault of the Truman administration, which was seriously embarassed..$^{53}$ On May 18, Clayton returned to Washington to try and prevent the passage of the wool bill, which, he believed, was putting the whole ITO project at risk. ${ }^{54}$ The bill passed anyway, but on 26 June Truman exercised his veto. But although the worst-case scenario had been averted, Clayton still lacked the authority to offer a cut in the wool tariff - and he would not get it until early August. This meant that the Geneva tariff talks would for the time being remain stalemated.

By this time, it had become clear that the British and the Americans viewed the negotiations very differently. During May, James Helmore had suggested that the US insistence on obtaining, in return for its own concessions, equivalent concessions from other countries, would not bring about a world in which there would be a minimum of trade restrictions. If the Americans really wanted to reach a liberal international trade regime, he suggested, they needed to make unequal bargains that would hurt some US industries. An equal AngloAmerican bargain on tariffs and preferences would only prolong the period during which Britain would be forced to take advantage of balance-of-payments exemptions to quantitative restrictions rules 
under the ITO charter. ${ }^{55}$ When Helmore wrote to Clayton along these lines, the latter rejected the 'fundamental inequity' of this approach. But Helmore received ministerial support: Harold Wilson backed him up, and it seems likely that Cripps supported his general position too. ${ }^{56}$

Moreover, Cripps himself now began to play down in public the overall significance of the Geneva talks. In a speech in Dundee on 11 June, he noted the fundamental economic imbalance between the USA and the rest of the world, whereby America continued to export $\$ 500$ million of goods each month more than she bought. This situation, he said, could only be remedied if 'some very special and exceptional steps' were taken to deal with it. He argued that the creation of an ITO and the reduction of tariffs and preferences would not alone be enough to solve the problem, and he was undoubtedly right. ${ }^{57}$

Cripps's talk of 'very special and exceptional steps' was almost certainly a reference to the the recently-announced Marshall Plan. Secretary of State George Marshall's famous Harvard speech was delivered on 5 June, and radically changed the landscape in which the ITO negotiations took place. Welcome though it was, the British remained deeply anxious about their economic situation. On 23 June Cripps briefed the editor of the Times that Britain's dollars were 
running out fast and might be gone by November. Moreover, he thought that Clayton was too wedded to the ITO, 'but perhaps [was] less obsessed by "non-discrimination"' than he had been previously. ${ }^{58}$ Indeed, during this period the Americans maintained a public facade of strict adherence to the non-discrimination clause of the loan agreement, but were accomodating in private. ${ }^{59}$

Although the British found the Americans supportive in this regard, the UK attitude to the Geneva talks was causing the US concern. In late June, Clayton complained to Cripps that both in relation to tariff matters and to the Charter discussions the British delegation had not given the USA the measure of support to which they were entitled. Cripps 'was at some pains to make it clear to Clayton how erroneous this view was ... there was no question of our support for the ITO Conference being half-hearted'. Clayton suggested that Cripps should make his attitude obvious to the world by returning to Geneva to take a further part in the proceedings. Cripps indicated his willingness to comply. ${ }^{60}$ The US delegation hoped to use Cripps's visit to Geneva to 'put the screws on the British'. ${ }^{61}$ They believed that, by the time he arrived, they would have received authority to offer a cut in the wool tariff. A new offer to Australia would remove Britain's excuse for inaction on preferences. Breaking the stalemate with the Southern Dominions would help bring pressure to bear on the UK: 'Situation 
would also enable us simultaneously to strike hard on all other fronts where negotiations are now lagging. ${ }^{62}$

Cripps had his own reasons for accepting the invitation. A brief provided to him on 10 July - a few days before sterling was made convertible under the terms of the loan agreement - argued that the non-discrimination provisions of the draft ITO charter would bear particularly heavily on Britain as compared to other countries when it came to gaining exemption on balance of payments grounds. This was because, it was argued, alone of any country that was likely to have recourse to the exemption procedure, Britain had accepted the full convertibility obligation of the IMF and therefore needed to get the approval of both the Fund and the ITO before acting to protect her balance of payments. Moreover, the brief suggested, this also meant that British efforts to maintain the convertibility of the pound would have to contend against a widespread freedom for other nations to discriminate against Britain. 'In order to break the present deadlock in which the Americans refuse to give their mind to this very real problem an approach at the highest level is required. ${ }^{\prime 63}$ Geneva was not merely a convenient location for Cripps to make such an approach. If the British were to ask to be let off the hook, it was best to do it whilst simultaneously and visibly affirming a commitment to 
the ITO as a whole, and a high-level ministerial visit to the talks was an ideal way to achieve this.

Cripps arrived in Geneva on 11 July. The American plan to 'put the screws on' was confounded, however, as authority to offer the wool tariff cut had not yet been received. ${ }^{64}$ Cripps's first meeting with Clayton accordingly caused the Americans deep frustration and pessimism. ${ }^{65}$ The Americans made a presentation comparing the US and UK offers, pointing out that the US had requested the elimination of preference on about 65 items, but the UK had offered elimination on only three minor items, namely chilled or frozen salmon, motor bicycles and motor tricycles. Cripps hit back, arguing that the British and American offers were in balance. (The British case was that, whilst offers of complete elimination were slight, offers of reductions of preferential margins covered over forty per cent of the US requests; and that as most of Britain's tariffs were already very low, even much more generous offers would not compare favourably with the kinds of swingeing cuts the Americans could make in their much higher tariffs.) He 'frankly did not think it possible to go further'. He said that if the United States felt there was no fair balance of offers the only way out would be for the Americans to withdraw some of their own offers. ${ }^{66}$ The Americans were distressed. ${ }^{67}$ 
According to Clair Wilcox, however, when the British and Americans reconvened two days later, "The British displayed an over-zealous attitude to cooperate in the establishment of the necessary conditions for the revival of world trade. ... Mr. Clayton and Sir Stafford reached an understanding on all outstanding issues. ${ }^{68}$ Wilcox attributed the apparent change of heart to a reassessment by the British, who, he believed, 'had reached the conclusion that their attitude toward cooperative effort to reduce and eliminate trade barriers was alienating the friendship of the United States' - and had thus taken steps to repair the damage. ${ }^{69}$ Yet, if the British made greater efforts to be friendly, their fundamental attitude had not changed in the way that the Americans surmised.

At the beginning of the second meeting, Clayton reminded Cripps of the secret Anglo-American agreement of 1945, whereby if the Dominions were to adopt an unreasonable position regarding the elimination of preferences, the UK would denounce its agreements. He had no intention at this stage, he said, of asking the British to do this, but was merely stating the facts for the record. Cripps responded that 'he remembered the facts quite well'; and although he continued to stress that Britain could not act unilaterally, he also stated 'that the United Kingdom was prepared, if they came to the conclusion that the Dominions were acting unreasonably, to bring pressure on the 
Dominions. ${ }^{70}$ This - along with Cripps's stated willingness to consider a method whereby given preferences would be eliminated progressively over a period of five years - seems to have favourably impressed the Americans. They seem to have convinced themselves that Cripps had agreed to the gradual elimination of preferences, even though, as Wilcox acknowledged the very next day, 'Sir Stafford was not pressed to make definite commitments with respect to Empire preferences'.$^{71}$ They overlooked the fact that, even if he was prepared to bring pressure to bear on other countries - and in fact he was not prepared to do so to any great extent - he still laid emphasis on commonwealth consent.

The British assessment of the outcome of the meetings was also much too sanguine. Cripps told his cabinet colleagues that the UK and US offers were in approximate balance, the scales being tipped perhaps somewhat in Britain's favour; it was not, in his view, necessary to go much further to meet the Americans, although he would be prepared to add 'a few more concessions of not too substantial a nature ... if it finally proves necessary to do so in order to secure an agreement.' He seems not to have been aware of how much further the Americans wanted him to go. He certainly did not believe that he had agreed to the elimination of preferences. He believed that he had succeeded in making it clear to Clayton that the countries at whose expense 
reductions in preference were made - rather than the countries which granted preferences - should be the recipients of compensation in terms of tariff cuts. Yet he overlooked the importance laid by the Americans on British action to persuade commonwealth countries to give up the preferences they received: 'it is in the main for the Americans to persuade them that they have been offered adequate advantages in return. ${ }^{72}$

There had, in fact, been a major failure of understanding. This is clear from the minutes of a meeting of the US delegation held two weeks after the Cripps-Clayton conclave:

the British seem to be taking an entirely different point of view with respect to the agreement reached between Sir Stafford Cripps and Mr. Clayton a short time ago on the elimination of Empire preferences. The British now interpret the commitment made by Sir Stafford Cripps as meaning that Sir Stafford had accepted the US request for the gradual elimination of Empire preferences on behalf of the Dominions but without having first consulted the Dominions. Consequently, the commitment made by the Sir Stafford Cripps is meaningless unless the Dominions agree. ${ }^{73}$

In fact, Cripps had made no 'commitment'; as the Americans now realised, his position was simply that, if the Dominions could be persuaded to relinquish the preferences accorded them, he would be happy for this to happen.

In the meantime, Cripps continued to endorse the ITO publicly, to the gratification of the Americans. ${ }^{74}$ However, the UK's commitment to the 
project weakened as its economic situation deteriorated. Sterling was made convertible on 15 July. In the weeks afterwards, the dollar drain, already a major cause of concern, began to accelerate. On 24 July the Chancellor, Hugh Dalton, told the cabinet that at the present rate of drawing, the US loan might be exhausted by late September. ${ }^{75}$ On 28 July, the Foreign Office sent a telegram to the British embassy in Washington. Given the chronic dollar situation, it said, Britain would 'within the next few months be faced with necessity of having to take drastic action to enable us to secure the barest minimum of supplies from overseas by means of measures which would be quite inconsistent with the Draft [ITO] Charter.' Given the proposed timetable for the interim General Agreement on Tariffs and Trade being signed and coming into force, it suggested, the British were faced with a dilemma. They could (a) agree in September to bring into force in November an agreement containing provisions about nondiscrimation which they might find themselves unable to carry out because they had no dollars, or (b) refuse to agree to any provisions about non-discrimination, either in the draft charter or in the GATT, in which case a mortal blow might be struck at the whole project of bringing the world back to multilateralism. (As things stood, the UK was pledged under the loan agreement not to discriminate against the USA, but was free to discriminate against other countries.) 'This is a project which we firmly believe is in our long-term interests as much of as those of any other country, but in our short-term situation our lack of dollars might be over-riding. ${ }^{76}$ 
At a meeting in Paris, Cripps put the UK's message bluntly to the Americans, making clear that the UK was desperate and that shortrun considerations for the time being outweighed all long-term interests. ${ }^{77}$ The British were now proposing that the GATT, which by now was largely complete in draft, should only be initialled ad

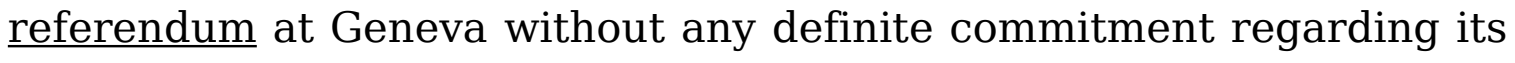
coming into force. This would be a body blow against the whole project of trade multilateralism, as it would be very difficult to enact the Geneva tariff reductions without any general rules governing them. Finally it came out that the British would feel able to go ahead with the GATT if the nondiscrimination rule was only to become effective at the point when the ITO charter came into force. The Americans accepted that the British should be granted some additional breathing space - until the end of 1948, as it eventually turned out - and the Geneva talks were saved. ${ }^{78}$ Again, the British had used the fact of their own economic weakness as a lever to extract concessions from the United States.

Moreover, on 2 August, the American delegation received the longawaited authority to cut the wool tariff (by 25\%). ${ }^{79}$ But this did not have the hoped-for effect of kick-starting the stalled tariff talks. A new US approach to Helmore, involving a short-run relaxation of restraints on discrimination and an easing of US requests on preferences, 
brought no response. ${ }^{80}$ The Americans now suspected that the British were merely paying lip service to the negotiations, whilst intending 'to get away with just as little performance as possible'. They determined to go on the offensive, by putting their case to Cripps in London. ${ }^{81}$ The meeting was scheduled for 20 August. That day, convertibility was suspended. This was a major blow at the hopes of restoring multilateral trade. As Harold Wilson commented in November, "The multilateral, all-convertible trading world envisaged in 1945 crashed in the summer' ${ }^{82}$

Clayton's meeting with Cripps produced another stand-off: 'Mr. Clayton ... said that in his opinion under the spirit of the arrangement entered with the U.K. the United States was entitled to more than the U.K. had offered. Sir Stafford replied that the spirit was that the U.K. would enter into negotiations. ${ }^{\prime 83}$ Part of the problem - aside from the continuing difficulties of interpreting the 1945 agreement - was that they could not agree a basis for assessing the value of respective concessions. Whereas the Americans made their calculations mainly on the basis of the percentage of items on which duties were reduced, the British made theirs based on the pre-war value of trade in items on which duties were to be bound or reduced. On this basis, the British could claim bindings and reductions of rates covering trade totalling $£ 10,095,000$ and $£ 17,453,000$ respectively, as against US 
totals of $£ 8,083,000$ and $£ 17,000,000$ respectively. ${ }^{84}$ Clayton produced a short list of 'essential demands' for eliminations and further reductions. Cripps - who said that 'spectacular eliminations' would be politically impossible - promised to refer the list to his colleagues but warned that the likely response would be negative. It was always open to the Americans, he reiterated, to withdraw some of their own offers. $^{85}$

In the wake of the meeting, Cripps told the cabinet that there is no doubt at all that the Americans (and particularly Mr. Clayton) are genuinely convinced that they have made a generous offer' to the participants in the Geneva talks, 'and that they have been greatly disappointed with the responses they have received.' The American message did at last seem to be getting through, although Cripps was still reluctant to go as far as the US side wanted: 'we should attempt to meet the Americans halfway on their new requests (in themselves very much less than their original demands) and to endeavour to get really worthwhile concessions in return.' The 'fairly substantial' concessions he now envisaged making were in the form of eliminations of preference, to which Clayton attached great importance, rather than reductions. ${ }^{86}$ Clearly, the stern US message had produced some significant movement on the British side. Nevertheless, Cripps's uncompromising demeanour at the 20 August 
meeting - perhaps adopted because he doubted that he could convince his own cabinet colleagues to share his views - disguised this change of heart from the Americans. The British embassy in Washington warned on 23 August that Clayton had recommended that the United States should break off the multilateral negotiations at Geneva on the grounds that the United Kingdom was unwilling to reduce its preferential tariffs; although it was unlikely that this advice would be accepted without further efforts to find a solution. ${ }^{87}$

Ironically, this recommendation came at a point when the multilateral negotiations had achieved a substantial success - the completion of the draft ITO charter. The Americans had been forced to make some significant, but not fatally damaging, concessions over nondiscrimination, new regional preferences, and the use of quantitative restrictions in the interests of economic development. ${ }^{88}$ The British had favoured the freedom to discriminate and to employ quantitative restrictions in the interests of solving balance of payments problems; but they had worked with the Americans in attempting to resist pressure from the less-developed nations. Alarmingly for the Americans, however, during the round of speeches that marked the completion of the draft agreement, Harold Wilson offered a stark warning. In the coming months and years, he said, Britain would have to use methods which 'may appear to be opposed to the principles and 
methods of the draft charter'. These new methods would include bilateral agreements. ${ }^{89}$

Wilson's 'funeral oration' on multilateralism, made in the light of the suspension of convertibility, represented, in terms of Britain's public position, a major change of tack. ${ }^{90}$ He himself - often prone to exaggerate his own role in events - subsequently claimed in private to have been acting on his own initiative. ${ }^{91}$ Yet it is scarcely conceivable that a junior minister would have instigated such a major policy departure without the consent of his superiors, whose views, undoubtedly, the speech reflected. Cripps explained publicly a few weeks later that the continued dollar shortage 'drives us inevitably into the necessity of bilateralism'.92 As Wilson later remarked, 'Stafford had begun by being all out for the American policy, but as the extent of America's real willingness to make real contributions revealed itself day by day as something smaller and smaller, Stafford had changed. ${ }^{93}$

All the same, the extent of the British change of heart should not be overstated. Cripps certainly did not want the tariff talks to break down. Indeed, he was taking greater steps than ever before to meet the Americans on the elimination of preferences, even while he was contemplating new bilateral trade deals with other countries. He had 
not abandoned hope that the GATT could be signed, and that the ITO would in due course come into being. But what he wanted was a 'thin' multilateral agreement, Britain making as few trade concessions as possible, and remaining free to pursue discriminatory methods to the maximum possible extent. Thus, in due course, the UK did both sign the GATT, and conclude bilateral trade agreements not only with individual commonwealth countries, but with Denmark, Sweden, Argentina, and the USSR. ${ }^{94}$

In the meantime, the Geneva talks had been running into deeper trouble. Cripps's revised list of offers on preferences had met opposition from within the British government, on the ground that it was excessively generous. Attlee had 'Grave doubts about the whole thing'; there were 'Vague rumblings' from Herbert Morrison, the Lord President; the Commonwealth Relations Office thought it would 'break up the empire'. ${ }^{95}$ In response, Cripps modified the list of proposed eliminations somewhat, but otherwise pressed ahead. ${ }^{96}$ At the same time, the government searched for new options in the trade field. On 3 September Bevin, after consulting Cripps, floated publicly the notion of a commonwealth and empire customs union. ${ }^{97}$ This seems to suggest a rather panicky casting around for ideas, and the inter-departmental committee established to consider the concept's 
feasibility quickly saw that it was not likely to be realisable under existing conditions. ${ }^{98}$

The Americans too were divided about what to do if, as seemed likely, the British rejected the most recent US demands without making acceptable counterproposals. Truman shared the State Department's opinion that the best course was 'to get [the] best agreement possible in present highly unfavourable circumstances and reserve part of our negotiating position for use at more propitious time by trimming our offers accordingly' - exactly in the manner that Cripps had suggested. ${ }^{99}$ Clayton, however, was reluctant to settle for a 'thin' agreement.

By 9 September, the Americans were in receipt of the British counterproposals and new offers from the commonwealth. Although the Americans were prepared to negotiate on the basis of the Commonwealth offers, those of the British were found to be unsatisfactory. (The realisation of this came as shock to the British, who had assumed that their attitude would be regarded by the US as more conciliatory than that, say, of Australia and New Zealand). ${ }^{100}$ On the $15^{\text {th }}$, Clair Wilcox gave a 'crackerjack' speech to the commonwealth delegates in Geneva. ${ }^{101} \mathrm{He}$ gave a statistical presentation, seeking to show that the percentage of preferences 
covered by the new UK offers was inadequate when measured against the percentage of US tariffs on which reductions had been offered. He rejected the idea that the Americans should withdraw some of their own offers. Yet, he said, the Americans would not yet acknowledge failure and would therefore suggest a new approach, relating only to the preferences that the UK enjoyed throughout the commonwealth and empire. A new list of elimination requests would be presented; after a three-year postponement, the elimination would take place over the course of ten years. Wilcox finished his speech by suggesting that the alternatives to this approach - the conclusion of a thin agreement, or the termination of US negotiations with Britain - would both jeopardize the Marshall Plan. His message was clear: if Britain did not seize the nettle the Americans would have no alternative but to recommend breaking off negotiations. ${ }^{102}$

There was, however, a strong element of bluff in this, given that both the State Department and the President himself were inclined to accept a thin agreement in preference to breaking-off discussions with the UK. The British, for their part, were aware that the tough talk of the Americans in Geneva did not necessarily reflect US government opinion as a whole. ${ }^{103}$ This made it easier for them to maintain their own stubborn line, a fact which underlay Cripps's attitude when, on 19 September, he met with Clayton in London. 
There was the by now familiar wrangling over the correct interpretation of Article VII, the loan agreement, Attlee's 1945 Commons statement, and the precise meaning of 'adequate compensation'. After denouncing the UK offers as 'totally inadequate', Clayton handed over his proposal for gradual eliminations over the long-term.

Sir Stafford said that he was prepared to put forward the U.S. proposal to the Cabinet but that he would feel obliged to recommend them not to accept it. He said that it would be "quite impossible to put over anything substantially more than has been done". He stated that there was a large number of people who would not shed tears if the negotiations broke down altogether. ${ }^{104}$

Following the meeting, Clayton and Douglas decided that the situation was now so fraught with danger that they should have a talk with Bevin, before Cripps made his recommendation to the cabinet. This meeting (referred to at the start of this article), which Cripps also attended, took place on 22 September. Bevin's private secretary noted in his diary: 'A busy day in the Office, with Clayton and Douglas next door trying to blackmail E.B. and Cripps into dropping imperial preference under threat of no help for Britain under the Marshall Plan. ${ }^{105}$ Bevin hit back strongly:

The Foreign Secretary said that he did not think he could be much influenced in this matter by the Marshall offer. ... If the US felt unable to grant us aid because of our attitude in the Geneva negotiations that was their affair. The Marshall Plan was 
a US plan and if it now broke down they would suffer. He also pointed out that if the US publicly accused this country of repudiating its obligations we should be bound to state our side of the case. ${ }^{106}$

Bevin can hardly have been as indifferent to the US threats as he made out. He may, however, have found them unconvincing. He and Cripps may have thought that Clayton did not have the authority to pull the plug on the Marshall Plan - the exclusion of the British being likely to lead to its collapse - and that the less 'fanatical' elements in the State Department would ultimately override him, allowing a bargain on preferences along the lines that Cripps wanted. Nevertheless, in his advice to the cabinet, Cripps conceded the possibility that Clayton, 'exasperated by the frustration of his undoubtedly sincere hopes', might 'induce his colleagues to do in haste what they may regret at leisure.' He put his faith in the idea of an appeal direct to Marshall, and asked for authority to refuse further concessions and notify Clayton accordingly. The cabinet readily granted it. Cripps sent a letter to Clayton, saying that to agree to the American proposals would mean promising to take action three years later in circumstances which could not be foreseen, without adequate concessions in return. ${ }^{107}$ Douglas feared this letter would be viewed in Washington as 'a flat repudiation', and asked that the text be amended. ${ }^{108}$ Cripps refused to modify it, although he stressed that the British would remain open to new approaches. ${ }^{109}$ 
Nevertheless, the situation, which appeared dire, was rescued. Winthrop Brown had become convinced that the overall results of the tariff negotiations between all countries were so great that they could not be lost: 'This total accomplishment just had to be saved somehow. $^{110}$ On Tuesday 1 October, in Geneva, he approached Helmore for a private talk. He said that he had endeavoured to secure from Washington a promise that no message breaking off negotiations would be sent until after the week-end. He hoped that before that point, he and Helmore could work out, without commitment, something which both men could recommend to their respective governments. Helmore was cautious, but agreed to spend the next two days in intensive one-to-one discussions with Brown. ${ }^{111}$

The proposals that Brown and Helmore came up with involved abandoning the US plan for the gradual elimination of preferences over thirteen years. Britain's 9 September offers would stand, but without disturbing the overall balance of the Anglo-US offers - she would make some adjustments so as to increase the number of preference eliminations. Moreover, in return for an all-round reduction of $25 \%$ in the margins of preference that Britain enjoyed in the colonies, the USA would make a concession on its rubber mixing regulations. ${ }^{112}$ Helmore travelled back to the UK to try and sell the 
proposals to his political masters. Wilson - newly appointed President of the Board of Trade - felt that they were economically sound, but believed they would present major political difficulties, particularly in respect of the proposed reduction in the preference that Rhodesian tobacco received in the British market. Cripps - now Minister for Economic Affairs - was non-committal. However, when he and Wilson met with Bevin on 8 October the latter rejected outright the all-round reduction in colonial preferences. He refused to reconsider this decision and was supported by Cripps. ${ }^{113}$ The next day, the cabinet approved the proposals, minus the colonial concession. ${ }^{114}$

The Americans, however, were insistent that the colonial concession must stand. ${ }^{115}$ Five days later, the British agreed, clearing the way for the signature of the GATT on 30 October. Indeed, from the perspective of Cripps and the British, the arguments in favour of the compromise were overwhelming. The Helmore-Brown proposals did very little to undermine the imperial preference system (which remained in existence until Britain joined the EEC). They involved no future commitment which Britain might find herself unable to implement when it matured. Britain's hands were not tied with regard to the future except to the extent that she was already committed to the elimination of preferences on a 'mutually advantageous' basis. The concessions which Britain was asked to make might be painful, but their effects were measurable and finite. They were thus far less 
objectionable to the British than the previous American offer. ${ }^{116}$ In addition to this, agreement would help prevent a rupture with the Americans that would be damaging in the extreme. In comparison with this danger, the economic and political effects of the colonial concession were of little significance. ${ }^{117}$ The bold attitude of the British, which combined reminders of the UK's own economic weakness with protestations of indifference to American threats, had paid off.

The conclusion of the Geneva negotiations represented a major achievement. Not only had the American tariff had been reduced to its lowest level since 1913, securing substantial reciprocal concessions from other countries, but, as Gardner has noted, the GATT itself had a significance which went beyond the specific tariff and preference concessions. It provided a forum for the discussion of trade problems and a mechanism for future trade negotiations, as well as providing a set of commercial policy principles to ensure that tariff concessions would not be offset by other types of trade restriction. ${ }^{118}$ Although it was supposed to be an interim agreement, it survived for the best part of fifty years, before being superseded by the WTO. It was a major contributant to the growth of world trade post-WWII, growth which in turn contributed to the prosperity of the 1945-73 era. 
But if the outcome of the Geneva talks was a success, it is tempting to ask why the process of negotiation itself was so agonising, and why the discussions came so close to breakdown. At the start of the conference in April, nobody had imagined that it would continue throughout the summer. ${ }^{119}$ To some degree, there had been an underestimate of the technical difficulties that would be involved; certainly, subsequent GATT rounds did not get any shorter. But political problems also played a major part in dragging things out. Some of these problems were external to the negotiations, in the sense that they could only be resolved by actions away from the immediate context of Geneva. Congress's action on the wool tariff, and the UK's profound economic crisis, are the key examples. There were also problems internal to the talks. The British took a long time to wake up to the reality of the American position. Not until August did Cripps seem to realise that he would have to come up with new concessions in order to reach a deal, and even then his cabinet colleagues were hard to persuade.

There was, furthermore, a major cleavage in view between the views of the British and the Americans. There was also a mistrust by British politicians of the Board of Trade officials in Geneva, whom, it was felt, were insufficiently wary of their US counterparts. These facts are clear from private comments made by Harold Wilson in early October: 
he thought James Helmore very clever but felt that he had come to place excessive importance on a successful outcome of the tariff negotiations. He said James had got almost too close to the Americans. Also, of course, any person in charge of any negotiation was apt to come to believe that success in that particular thing was vital, in short to lose somewhat a sense of proportion. Many of the Americans involved, the nicest of fellows, had been on the job so long that they too had begun to think more of a successful outcome of their long labours than of the real merits of the resulting arrangement in a world which had changed a great deal since Cordell Hull saturated the State Department at Washington with his almost religious convictions on the subject of Tariff reductions. The Americans at Geneva, he thought, tended to fail to see the world as it really was today. ${ }^{120}$

As Gardner has argued, the US emphasis on the 'elimination' of preferences - on which Clayton in particular put so much emphasis served to alienate British opinion and to distract attention from the broad advantages likely to be obtained from a multilateral settlement. ${ }^{121}$ In addition, American confusion about the precise nature of Britain's obligations led to the accusation, which was not fully justified, that the British were repudiating their agreements. This accusation was guaranteed to cause bad feeling, and helped edge the talks near to breakdown.

Furthermore, as the Canadian ambassador to the United States commented at the beginning of October, 'It is evident that the temperamental differences between Clayton and Cripps have grown to a point at which they constitute a real obstacle to agreement.'122 
Therefore, it fell to officials further down the ladder to work out proposals which, in the end, proved acceptable to both sides. Nevertheless, Cripps does deserve a substantial measure of credit for the end result. However stubborn he may have appeared to the Americans, he never shut the door on new approaches; indeed, once it became clear to him that more British concessions were needed, he pressed his ministerial colleagues to go much further than they would have wished.

Overall, though, consideration of Cripps's general attitude to the talks provides further support to the argument that there was no warm embrace by the Attlee government of the American position on trade. ${ }^{123}$ And at a broader level, the Geneva talks episode raises questions about the nature and extent of US hegemony during this period. The US failure to secure the abolition of the imperial preference system as the price of post-war aid to Britain suggests an important failure of hegemonic imposition. This, on the face of it, is surprising, given that the USA was so much more politically and economically powerful than the UK. One is bound to ask, then, why the methods that the Americans used to persuade the British to comply with their wishes did not work. 
The artifice that Clayton and Douglas employed at their 22 September 1947 meeting with Cripps and Bevin was evidently not blackmail. They were not demanding money in return for concealing discreditable British secrets. They were attempting to use - although they did not think of it in these terms - the device of policyconditioned aid. They wanted, in exchange for making Marshall aid available to the UK, a change of British commercial policy on trade preferences for the commonwealth and empire. Since then, the instrument of policy-conditioned aid has undergone more than fifty years of evolution, both in bilateral and in multilatreal lending contexts. ${ }^{124}$ In view of the current scepticism about the effectiveness of aid conditionality, ${ }^{125}$ it is significant that this early example of its use was a spectacular failure. Indeed, the attempt to employ it in 1947 was only necessary because an earlier attempt - the US effort to make the 1945 loan conditional on a substantial contraction of the imperial preference system - had already failed.

Clayton and Douglas's method did not work largely because the US government had multiple objectives. Its desire for some form of trade agreement and its wish to include Britain in a European recovery programme ultimately proved stronger than its dislike of the continuation of the imperial preference system. The Attlee government, although its conduct of the negotiations was by no means 
infallibly sure-footed, was able to exploit this situation in an effective manner. This victory for David over Goliath was explicable in large part by the problems inherent in the seemingly powerful device of attaching policy conditions to large-scale foreign aid.

Wider lessons can also be drawn. In recent years, scholars have been increasingly willing to emphasise the limitations of using US 'hegemonic power' as an explanation for the emergence of the postWWII international economic order. As G. John Ikenberry has noted, 'the system was shaped by Great Britain as well as by the United States and in ways that would be unanticipated by simple considerations of power. ${ }^{126}$ The Geneva episode supports this claim. It shows that (as Peter Burnham has argued with respect to the 1945 loan agreement) the United States was on important occasions unable to translate its economic power into particular desired negotiating outcomes. ${ }^{127}$ The Attlee government - steadfast, and sometimes almost quixotic, in its determination - did not capitulate to American dominance. This is by no means to say that the overall result of the talks was unsatisfactory to the Americans, but merely that, for them, the achievement of a successful all-round outcome necessarily involved compromise with individual, far less powerful, allies. The failure of Clayton and Douglas's attempt to force Cripps and Bevin to surrender imperial preference thus demonstrated that power does not 
merely result from the possession of superior resources. It is a product of how those resources are wielded, and the attitudes and capabilities of those over whom one would exercise it. Coercion is rarely the straightforward solution it may sometimes appear. 
${ }^{1}$ I would like to thank Till Geiger, John Toye and two anonymous referees for comments on an earlier draft of this article. I would also like to thank James N. Miller for supplying me with copies of material from the Harry S. Truman Library in advance of my own visit, for allowing me to read sections of his Ph.D. thesis prior to submission, and for many useful discussions. Errors that remain are, of course, my own responsibility.

2 Public Record Office, Kew, London (hereafter PRO) BT 11/3647, 'Note by President [of the Board of Trade]', 22 September 1947.

${ }^{3}$ See Alan Bullock, Ernest Bevin: Foreign Secretary 1945-1951 (London, 1983), p. 462.

${ }^{4}$ For a compelling account of Labour's attitude to imperialism during this period, see D.K.

Fieldhouse, 'The Labour Governments and the Empire-Commonwealth', in Ritchie Ovendale (ed.), The Foreign Policy of the British Labour Governments 1945-1951 (Leicester, 1984), pp. 83-120.

5 For general accounts, see Peter Hennessy, Never Again: Britain 1945-51 (London 1992); Kenneth O. Morgan, Labour in Power, 1945-51 (Oxford, 1984); Henry Pelling, The Labour governments, 1945-51 (London, 1984). For accounts focusing on economic policy as a whole, see Alec Cairncross, Years of Recovery: British economic policy, 1945-51 (London, 1985); G.D.N. Worswick and P.H. Ady, The British Economy 1945-1950 (Oxford, 1952); J.C.R. Dow, The Management of the British Economy 1945-60 (Cambridge, 1964); Jim Tomlinson, Democratic Socialism and economic policy: The Attlee years 1945-51 For accounts focusing on external economic policy, see Teddy Brett, Steve Gilliatt and Andrew Pople, 'Planned trade, Labour party policy and US intervention: the successes and failures of post-war reconstruction', History Workshop Journal xiii (Spring 1982), 130-42, and Peter Burnham, The Political Economy of Postwar Reconstruction (Basingstoke and London, 1990).

${ }^{6}$ Richard N. Gardner, Sterling-Dollar Diplomacy diplomacy in current perspective: The origins and prospects of our international order (New York, 1980), pp. 354-67.

${ }^{7}$ See James N. Miller and Richard Toye, 'Personality, Ideology and Interest in the Origins of the Modern World Trading System: The Case of Stafford Cripps and Will Clayton', in Frank Ninkovich (ed.), Global America, forthcoming.

8 Thomas W. Zeiler, Free Trade Free World: The Advent of GATT (Chapel Hill, North Carolina, 1999). 
${ }^{9}$ Marguerite Dupree (ed.), Lancashire and Whitehall: The Diary of Raymond Streat Volume Two: 1939-57, (Manchester, 1987), p. 316 (entry for 8 Jan. 1946), See also Richard Toye, The Labour Party and the Planned Economy, 1931-1951 (London, 2002, forthcoming), Chapter 7.

${ }^{10}$ This article therefore lends support to the critique of hegemonic stability theory put forward by Peter Burnham in The Political Economy of Postwar Reconstruction, and in 'Re-evaluating the Washington Loan Agreement: a revisionist view of the limits of postwar American power', Review of International Studies 18 (1992), pp. 241-59.

11 See James N. Miller, 'The Pursuit of A Talking Shop: Political Origins of American Multilateralism, $1934-1945^{\prime}$, Paper presented to the $25^{\text {th }}$ Meetings of the Eastern Economics Association, March, 1999; or for a fuller discussion, see Miller, 'Wartime Origins of Multilateralism, 1939 - 1945"' unpublished Ph.D. dissertation, University of Cambridge, 2002; and also Miller and Toye, 'Cripps and Clayton'.

${ }^{12}$ D.E. Moggridge, Maynard Keynes: An Economist's Biography (London, 1992), pp. 667-8.

${ }^{13}$ Susan Howson (ed.), The Collected Papers of James Meade Volume III: International Economics (London, 1988), pp. 27-35.

${ }^{14}$ Miller, 'Wartime Origins of Multilateralism'.

${ }^{15}$ See Toye, Labour Party, Chapter 7.

${ }^{16}$ PRO CAB 127/91, Stafford Cripps to Richard Law, 30 Dec. 1943.

${ }^{17}$ Susan Howson and Donald Moggridge (eds.), The Collected Papers of James Meade Volume IV: The Cabinet Office Diary 1944-46 (London, 1990), p. 106 (entry for 8 July 1945).

${ }^{18}$ In the immediate post-war years, the commonwealth entered a state of flux, not least as a consequence of the move to Indian independence. The term 'Imperial Commonwealth' had been in use as early as 1917. In 1931, the Statute of Westminster formalised the 1926 Balfour Definition, whereby the six Dominions then existing - the 'autonomous communities within the British Empire' - were recognised as 'members of the British Commonwealth of Nations'. In 1949, by which time there had been changes in membership, 'British' was dropped from the formal usage, and India became associated with the commonwealth as an independent republic. Britain, of course, also retained colonies, which, like the commonwealth countries, received trade preferences in the British market. See Alan Palmer, Dictionary of the British Empire and 
Commonwealth (London, 1996), pp. vii-viii, 26, 211, 271, 355-6.

19 See Cripps's comments on this subject: United States National Archives, College Park, Maryland (hereafter NA), RG 43 'Memorandum of Conversation: United States and United Kingdom Tariff Offers', 12 July 1947, International Trade Files (hereafter ITF) Box 83, and PRO BT 11/3646, draft British record of meeting, 12 July 1947. See also Gardner, Sterling-Dollar Diplomacy, pp. 154-5.

${ }^{20}$ See Tim Rooth, 'Britain's Other Dollar Problem: Economic Relations with Canada, 1945-50, Journal of Imperial and Commonwealth History, Vol. 27, No. 1, January 1999, pp. 81-108.

${ }^{21}$ Ross M. Robertson, History of the American Economy (3 ${ }^{\text {rd }}$ edn., New York, 1973), pp. 663-4.

${ }^{22}$ Walter Johnson and Carol Evans (eds.), The Papers of Adlai E. Stevenson Volume II: Washington to Springfield 1941-1948 (Boston, 1973), p. 258 (diary entry for 5-10 Sept. 1945)

${ }^{23}$ For a more detailed discussion, see Toye and Miller, 'Cripps and Clayton'.

${ }^{24}$ Susan Howson and Donald Moggridge (eds.), The Wartime Diaries of Lionel Robbins and James Meade, 1943-45 (Basingstoke, 1990), p. 226 (entry for 2 Oct. 1945).

${ }^{25}$ See Roger Bullen and M.E. Pelly (eds.), Documents on British Policy Overseas, Series I, Volume III (London, 1986), p. 200; Toye and Miller, 'Cripps and Clayton'.

26 Cmnd. 6709, 'Proposals for Consideration by an International Conference on Trade and Employment', 6 Dec. 1945.

${ }^{27}$ See Miller and Toye, 'Cripps and Clayton'.

${ }^{28}$ Foreign Relations of the United States (hereafter FRUS) 1945, VI, p. 152.

${ }^{29}$ PRO BT 11/2800, Telegram from Board of Trade to Washington, 22 Oct. 1945,.

${ }^{30}$ Parliamentary Debates House of Commons 5th series vol. 416, 6 Dec. 1945, col. 2668.

${ }^{31}$ PRO BT 11/2809, Telegram NABOB 308 J S M Washington to Cabinet Office (from Percivale Liesching) 8 Nov. 1945.

${ }^{32}$ See Francine McKenzie, 'Renegotiating a Special Relationship: The Commonwealth and AngloAmerican Economic Discussions, September-December 1945', The Journal of Imperial and Commonwealth History, Vol. 26, No. 3, September 1998, pp.71-93, at pp. 72-3.

${ }^{33}$ Although it has not proved possible to locate a copy of this statement in either the US National Archives or the British Public Record Office, in July 1947 Clayton reminded the British in detail of 
what had occurred. They did not dissent from the account that he gave. NA RG 43 'Memorandum of Conversation: United States and United Kingdom Tariff Offers (continued)', 14 July 1947, ITF Box 83.

34 PRO T247/2, Stafford Cripps, 'Commercial Policy and the Lend Lease Negotiations at Washington” 13 Sept. 1945.

${ }^{35}$ PRO CAB 128/4 CM(45)57 29 Nov. 1945 (confidential annex); R.W.B. Clarke diary 6 Mar. 1946, R.W.B. Clarke papers 25, Churchill College, Cambridge. See also Dupree, Streat Diary, p. 316 (entry for 8 Jan. 1946).

${ }^{36}$ PRO FO 371/62887, Telegram from Cripps to Bevin, 21 March 1947.

${ }^{37}$ Gardner, Sterling-Dollar Diplomacy, pp. 351-4.

${ }^{38}$ Cripps to Attlee, 8 Mar. 1947, Austin Robinson papers, Churchill College, Cambridge, ADDNL 7 ii).

${ }^{39}$ See Toye, Labour Party, Chapter 7.

${ }^{40}$ For an account of his life, see Gregory A. Fossedal, Our Finest Hour: Will Clayton, the Marshall Plan, and the Triumph of Democracy (Stanford, California, 1993).

41 See, for example, Judith Goldstein, 'Creating the GATT Rules: Politics, Institutions, and American Policy', in John Gerard Ruggie (ed.), Multilateralism Matters: The Theory and Praxis of an Institutional Form (New York, 1993), pp. 201-232, at p. 202.

42 Speech by Cripps at the opening of the Geneva conference, 11 Apr. 1947, Robinson Papers 6/6/3. For a general round-up of the first week's comment in the US press, including reactions to Cripps's speech, see NA RG 59 560.AL/4-1547, Telegram from State Department to US Delegation in Geneva, Apr. 1947. Items of particular interest in the British press can be found in The Spectator, 11 Apr. 1947, Tribune, 11 Apr. 1947, and the Manchester Guardian, 12 Apr. 1947. 43 PRO FO 371/62291 Telegram from UK delegation in Geneva to the Foreign Office, 12 Apr. 1947.

${ }^{44}$ PRO BT 11/3649, Telegram from Board of Trade to UK delegation in Geneva (Harold Wilson to J.C. Helmore), 16 Apr. 1947.

${ }^{45}$ Winthrop G. Brown oral history, p. 22, Harry S.Truman Library, Independence, Missouri. 
${ }^{46}$ NA RG 59 560.AL/5/647, Telegram from US delegation in Geneva to State Department, 6 May 1947.

47 The Americans, at the start of the talks, discerned weaknesses in the 'extremely badly organized' UK delegation. They noted that that little discretion had been given to the British negotiating teams, and that there seemed to have been little, if any, coordination between the earlier preparation of requests and the preparation of offers. NA RG 43 'Minutes of Delegation Meeting', 5 May 1947, ITF Box 133.

${ }^{48}$ Zeiler, Free Trade Free World, p. 100.

${ }^{49}$ NA RG 43, 'Minutes of delegation meeting', 29 April 1947, ITF Box 133.

${ }^{50}$ FRUS 1947, I, p. 926.

${ }^{51}$ PRO BT 11/2828 OEP (47) 29, Stafford Cripps, 'The Trade Negotiations at Geneva', 22 July 1947.

${ }^{52}$ William L. Clayton, 'GATT, the Marshall Plan, and OECD', Political Science Quarterly 78 (1963), pp. 493-503, at pp. 493-4.

${ }^{53}$ FRUS 1947, I, p. 916.

${ }^{54}$ Clayton, 'GATT, The Marshall Plan, and OECD', p. 495. See also Zeiler, Free Trade Free World, pp. 101-2.

${ }^{55}$ FRUS 1947, I, pp. 937-941.

${ }^{56}$ J.R.C. Helmore to Clayton 14 May 1947, Robinson Papers 6/6/2; FRUS 1947, I, pp. 945-7.

${ }^{57}$ NA RG 59 560.AL/6-1247, Telegram from US Embassy in London to Secretary of State, 12 June 1947.

${ }^{58}$ Robin Barrington-Ward diary, 23 June 1947, copy in Stafford Cripps Papers, Nuffield College, Oxford.

${ }^{59}$ Gardner, Sterling-Dollar Diplomacy, pp. 332-6.

${ }^{60}$ PRO BT11/3649 Telegram from Foreign Office to UK Delegation in Geneva (No. 838 FO), 28 June 1947.

${ }^{61}$ NA RG 43 Clair Wilcox to Paul Nitze, 12 July 1947, ITF Box 149.

${ }^{62}$ FRUS 1947 Vol. I , pp. 953-4. 
63 PRO FO 371/62305, TN(P)(SPECIAL)(CHARTER)(47)13, 'Non-Discrimination: Brief for the President of the Board of Trade', 10 July 1947.

${ }^{64}$ NA RG 43, Clair Wilcox to Paul Nitze 12 July 1947, ITF Box 149, and minutes of US delegation at Geneva, 10 July 1947, ITF Box 133.

${ }^{65}$ NA RG 43, Minutes of US delegation at Geneva, 14 July 1947, ITF Box 133.

${ }^{66}$ The US record of this section of the meeting is NA RG 43 'Memorandum of Conversation: United States and United Kingdom Tariff Offers', 12 July 1947, ITF Box 83. The draft British record, dated 12 July 1947, can be found in PRO BT 11/3646. See also PRO BT 11/3646, Telegram from UK Delegation in Geneva to the Foreign Office, 16 July 1947 (telegram c: 'Anglo American Tariff Negotiations') and NA RG 43, minutes of meeting of US delegation, 14 July 1947, ITF Box 133. As the Americans subsequently pointed out, the suggestion that if United States did not like the UK offers they should reduce their own was inconsistent with the previous British argument that United States concessions should, in order to achieve a proper balance, be better than those of other countries. See PRO FO 371/62313, Telegram from Washington to the Foreign Office, 23 August 1947.

${ }^{67}$ FRUS 1947, I, p. 965.

${ }^{68}$ NA RG 43, Minutes of US delegation at Geneva, 15 July 1947, ITF Box 133; see also NA RG 43 Postcript dated 14 July 1947, on letter from Clair Wilcox to Paul Nitze, 12 July 1947, ITF Box. 149.

${ }^{69}$ FRUS 1947, I, p. 965.

${ }^{70}$ NA RG 43, 'Memorandum of Conversation: United States and United Kingdom Tariff Offers (continued)', 14 July 1947, ITF Box 83.

${ }^{71}$ NA RG 43, Minutes of US delegation at Geneva, 15 July 1947, ITF Box 133.

${ }^{72}$ PRO BT 11/2828 OEP (47) 29, Stafford Cripps, 'The Trade Negotiations at Geneva', 22 July 1947; see also PRO BT 11/3646, Telegram from UK Delegation in Geneva to the Foreign Office, 16 July 1947 (telegram c: 'Anglo American Tariff Negotiations')

${ }^{73}$ NA RG 43, 'Minutes of General Staff Meeting', 30 July 1947, ITF Box 133.

${ }^{74}$ PRO FO 371/62305 Telegram from UK delegation in Geneva to Foreign Office, 14 July 1947; FRUS 1947, I, p. 965; NA RG 59 560.AL/7-1847, Telegram from US delegation in Geneva to 
Secretary of State, 18 July 1947.

${ }^{75}$ Ben Pimlott, Hugh Dalton (London, 1985), pp. 482-3.

${ }^{76}$ PRO CAB 21/2202, Telegram from FO to Washington embassy, 28 July 1947.

${ }^{77}$ NA RG 59 560.AL/8-147, Geneva to Secretary of State (for Robert Lovett from Clayton), 1 Aug. 1947.

${ }^{78}$ FRUS 1947, I, pp. 967-973.

${ }^{79}$ FRUS 1947, I, pp. 972-4; Zeiler, Free Trade Free World, pp. 102-3.

${ }^{80}$ FRUS 1947, I, pp. 974-6.

${ }^{81}$ NA RG 59 560.AL/8-1147, Telegram from Geneva to Secretary of State (for Lovett from Clayton), 11 Aug. 1947.

${ }^{82}$ Harold Wilson, 'Paying Our Way Abroad', in Douglas Jay et al, The Road to Recovery: Fabian Society Lectures given in the autumn of 1947 (London, 1948), pp. 89-98 at p. 97.

${ }^{83}$ NA RG 43, 'Memorandum of Conversation: Preferences the United Kingdom enjoys in Commonwealth and Empire countries', 20 August 1947. For the British account, see PRO CAB 129/20 CP(47)245, Cripps, 'Trade Negotiations in Geneva: U.S. Requests on Tariffs and Preferences', 27 Aug. 1947, Annex C. See also FRUS 1947, I, pp. 977-9.

${ }^{84}$ PRO CAB 129/20 CP(47)245, Cripps, 'Trade Negotiations in Geneva', 27 Aug. 1947, Annex F.

${ }^{85}$ NA RG 43, 'Memorandum of Conversation: Preferences the United Kingdom enjoys in Commonwealth and Empire countries', 20 Aug. 1947; PRO CAB 129/20 CP(47)245, Cripps, 'Trade Negotiations in Geneva', 27 Aug. 1947, Annex C.

${ }^{86}$ PRO CAB 129/20 CP(47)245, Cripps, 'Trade Negotiations in Geneva', 27 Aug. 1947.

${ }^{87}$ See PRO FO 371/62313 Telegram from Washington to the Foreign Office, 23 Aug. 1947. It is, of course, possible that this very warning, or other informal indications, stiffened Cripps in his resolve to offer concessions, given that his recommendations were not circulated to the cabinet until four days after it was received.

${ }^{88}$ Gardner, Sterling-Dollar Diplomacy, pp. 361-7; Report of the Second Session of the Preparatory Committee of the United Nations Conference on Trade and Employment (document E/PC/T/186), WTO archive, Geneva. See also JohnToye and RichardToye, Intellectual History of the United Nations Vol. 2 (Bloomington, Indiana, forthcoming), Chapter 2. 
${ }^{89}$ Speech by Wilson at the second session of the preparatory committee of the UN conference on trade and employment, $6^{\text {th }}$ meeting, 23 August 1947, WTO archive, Geneva; Gardner, SterlingDollar Diplomacy, p. 357;

${ }^{90}$ John Jewkes, Ordeal By Planning (London, 1948) , p. 231.

${ }^{91}$ Dupree, Streat Diary, p. 414 (entry for 8 Oct. 1947).

${ }^{92}$ NA RG 59, Telegram from US embassy in London to Secretary of State, 18 Sept. 1947, giving details of a speech by Cripps the previous day.

${ }^{93}$ Dupree, Streat Diary, p. 414 (entry for 8 Oct. 1947). Robert Hall, the recently appointed head of the Economic Section, who was to become one of Cripps's key advisers, shared the belief that multilateralism was impractical given post-war conditions. Alec Cairncross (ed.), The Robert Hall Diaries, 1947-1953 (London 1989), p. 5 (entry for 15 Sept. 1947).

${ }^{94}$ Harold Wilson, Post-War Economic Policies in Britain (London, 1957), pp. 4-5.

${ }^{95}$ PRO FO 371/62314 M, Minute by F.W. Marten, 4 Sept. 1947. See also PRO BT 64/2346 Arthur G. Bottomley to Cripps, 1 Sept. 1947.

${ }_{96}$ PRO BT 64/2346, Cripps to Attlee, 4 Sept. 1947.

97 Trades Union Congress Annual Report, 1947, p. 421; PRO FO 800/444, Bevin to Attlee 5 Sept. 1947. See also PRO FO 800/444 P.K. 47/128, Minute from Bevin to Attlee (copied to Dalton, Cripps and others), 16 Sept. 1947.

${ }^{98}$ Alan S. Milward, The Reconstruction of Western Europe, 1945-51 (London, 1984), pp. 243-4.

${ }^{99}$ FRUS 1947, I, pp. 980-1.

${ }^{100}$ FRUS 1947, I, pp. 982; Documents on Canadian External Relations, 13, 1947, p. 1171.

${ }^{101}$ Wilson T.M. Beale, Jr. to 'Yogsie', 17 September 1947, Wilson T.M. Beale, Jr. Papers, Truman Library. I am grateful to James N. Miller for this reference.

${ }^{102}$ FRUS 1947 Vol. I, pp. 983-93. See also PRO BT 64/2346 Telegram from Foreign Office to UK delegation in Geneva, 27 Sept. 1947.

${ }^{103}$ PRO BT 11/3647, 'American Tariff discussions: Note of a meeting in the President [of the Board of Trade]'s Room at 9.30 a.m. on Friday, September 19th [1947]'

104 NA RG 43, 'Memorandum of Conversation: United States and United Kingdom Offers', 19 Sept. 1947, ITF Box 83; PRO BT 64/2346 TN(P)(SPECIAL)93, 'Trade Negotiations Committee: 
Note by the Secretariat: Annex: Trade Negotiations with USA: Note of Meeting between Mr. Clayton and the President of the Board of Trade [on 19 September 1947]'; FRUS 1947, I, pp. 9935; PRO BT 64/2346 TN(P)(SPECIAL)(47)92, 'US attack on Preferences: Note by the Secretariat: Annex IV: Memorandum handed to Sir Stafford Cripps by Mr. Clayton [dated 19 September 1947]', 22 Sept. 1947; PRO FO 371/62317, Helmore to C.A.P. Brown, enclosing notes re. Clayton's arguments, 20 Sept. 1947: Note (a) 'The 1945 Undertakings'.

${ }^{105}$ Bullock, Ernest Bevin: Foreign Secretary, p. 462.

${ }^{106}$ PRO BT 64/2346 Telegram from Foreign Office to UK delegation in Geneva, 27 Sept. 1947. For the American account of the meeting - which does not record these words of Bevin on the subject of the Marshall Plan - see FRUS 1947, I, pp. 995-6.

${ }^{107}$ PRO CAB 129/21 CP(47)266, Cripps, 'The Tariff Negotiations at Geneva', 24 Sept. 1947; PRO CAB 128/10 CM(47)77"th 25 Sept. 1947; FRUS 1947, I, pp. 998-1003.

108 PRO FO 371/62318 UE 9021/37/G 'Conversation With the United States Ambassador: Mr. Bevin to Lord Inverchapel', 25 Sept. 1947.

${ }^{109}$ PRO FO 371/62318, Edmund Hall-Patch, 'Tariffs and Preferences', 26 Sept. 1947.

${ }^{110}$ Brown oral history, p. 27.

${ }^{111}$ PRO FO 37162319 Telegram from UK Delegation Geneva (Helmore) to Foreign Office, 2 Oct. 1947.

112 This meant that the proportion of synthetic rubber which, under US rules, had to be combined with natural rubber would be reduced. This would boost sales of natural rubber from Britain's colonial empire. FRUS 1947, I, pp. 1006-7; PRO CAB 129/21 CP(47)278, Harold Wilson, 'Trade Negotiations in Geneva: Tariff Discussions with the USA', 6 Oct. 1947.

${ }^{113}$ PRO BT 11/3648, TN(P)(47)149th Meeting: Minutes of the $149^{\text {th }}$ meeting of the UK delegation held in two parts on 10 and 11 Oct. 1947; PRO BT 11/3648 Helmore to Wilson, 'Tariffs and Preferences', 7 Oct. 1947; PRO FO 800/861, Bevin's engagement diary for 1947 (entry for 8 Oct.). ${ }^{114}$ Zeiler, Free Trade Free World, p. 119.

${ }^{115}$ FRUS 1947, I, p. 1010; PRO BT 11/3648, Telegram from Foreign Office to UK delegation in Geneva, 11 Oct. 1947; NA RG 59 560.AL/10-1047, 'Memorandum of Conversation [between Marshall and Inverchapel]: Geneva Trade Negotiations', 10 Oct. 1947. 
${ }^{116}$ PRO FO 371/62321, Memo by Hall-Patch (to Bevin) on imperial preference, 7 Oct. 1947.

${ }^{117}$ PRO CAB 129/21 CP(47)278 Harold Wilson, “Trade Negotiations in Geneva: Tariff Discussions with the USA', 6 Oct. 1947.

${ }^{118}$ Gardner, Sterling-Dollar Diplomacy, p. 361.

${ }^{119}$ Antony Gilpin memoirs, 'Chapter 10: Geneva', United Nations Career Records Papers MS Eng.4676 f.14, Bodleian Library, Oxford

${ }^{120}$ Dupree, Streat Diary, pp. 413-4 (entry for 8 Oct. 1947).

${ }^{121}$ Gardner, Sterling-Dollar Diplomacy, p. 360.

${ }^{122}$ Documents on Canadian External Relations, 13, 1947, pp. 1192.

${ }^{123}$ Toye, Labour Party, Chapter 7.

${ }^{124}$ For a review of policy-conditioned lending by the World Bank to developing countries, see Paul Mosley, Jane Harrigan and John Toye, Aid and Power: The World Bank and Policy-Conditioned Lending, 2 volumes, Routledge, 1985, $2^{\text {nd }}$ edn.

${ }^{125}$ David Dollar and Jakob Svensson, 'What Explains the Success or Failure of Structural Adjustment Programmes?', Economic Journal, 110 (2000), pp. 894-917. See also Burnham, 'Reevaluating the Washington Loan Agreement', p. 258.

${ }^{126}$ G. John Ikenberry, 'Creating Yesterday's New World Order: Keynesian “New Thinking” and the Anglo-American Postwar Settlement', in Judith Goldstein and Robert O. Keohane (eds.), Ideas and Foreign Policy: Beliefs, Institutions, and Political Change (Ithaca and London, 1993), pp. 57-86, at p. 61.

${ }^{127}$ Burnham, 'Re-evaluating the Washington Loan Agreement', pp. 258-9. 